\title{
Implications for diamond prospectivity from comparisons of diamond - bearing lithosphere in two Proterozoic orogenic belts
}

Pretorius, $\mathrm{W}^{*}$., Leahy, $\mathrm{K}$.

Department of Earth Sciences, Leeds University, Leeds, LS2 9JT, UK

(*presently at Apt. 5B, 165E 83rd St, NYC, NY, 10028, USA)

Diamond-bearing lithosphere existed beneath parts of two Proterozoic orogens: the (circa 3.0Ga) Central Zone of the Limpopo Belt, SA, and the Glennie Domain (at least 2.5Ga) of the Trans Hudson Orogen, Canada. These two Archean terranes encased within Proterozoic orogens are strikingly similar, but also have distinctive differences. They have not previously been regarded as cratonic regions and yet both have been intruded by diamondiferous kimberlites. Therefore these orogens highlight the limitations associated with applying Clifford's Rule when identifying diamond prospective regions.

\section{Limpopo Belt vs. Glennie Domain}

The central part of the cuspate Trans Hudson Orogen (THO) in Saskatchewan, Canada, is termed the Glennie Domain (GD), and prior to collision had an areal extent of at least $400 \mathrm{~km} \mathrm{x}$ $800 \mathrm{~km}$ (although now has a considerably smaller outcrop). The pod shaped GD is interpreted to be an Archaean microcontinent and was entrained within the $1.85 \mathrm{Ga}$ oblique collision between the Superior and the Hearne/Rae Cratons that formed the THO (Lewry et al, 1995). It has been imaged well on seismic reflection profiles e.g. LITHOPROBE. The LB is presently approximately $300 \mathrm{~km} \mathrm{x}$ $600 \mathrm{~km}$ and its Central Zone $(\mathrm{CZ})$ is apparently "exotic" due to its unique lead isotope signature (Barton et al, 1983), and was emplaced from the south-west (McCourt \& Vearncombe, 1992), during the Main collisional event between the Kaapvaal Craton (KVC) and the Zimbabwe Craton (ZC) circa $2.7 \mathrm{Ga}$.

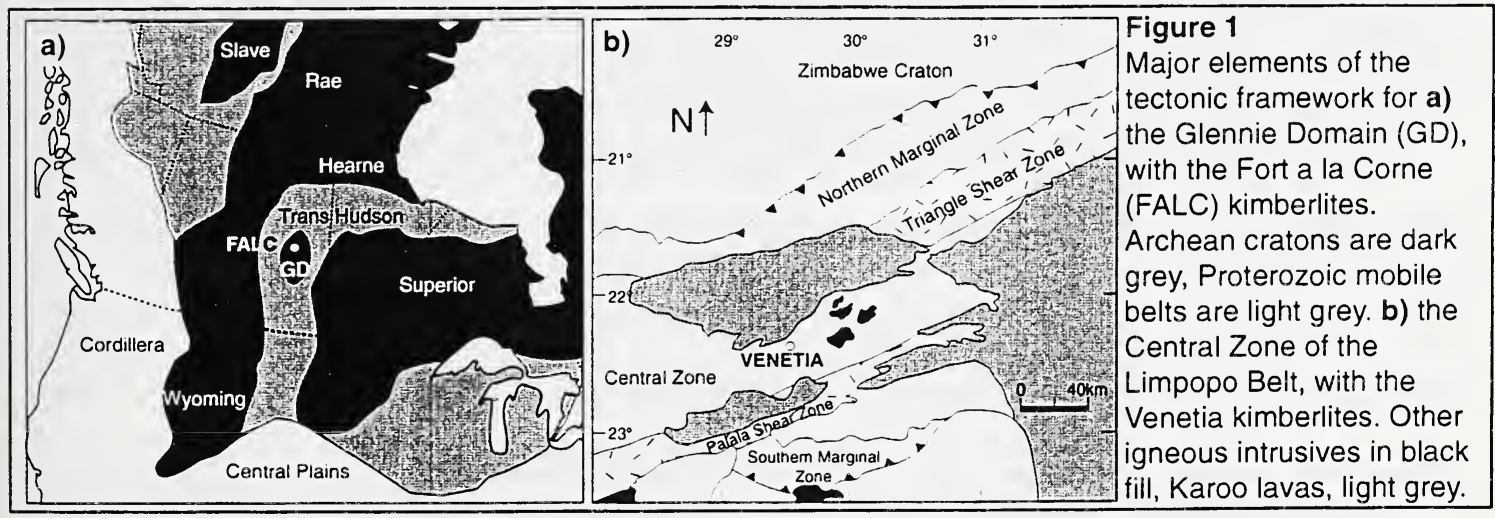

The present crustal thickness below the GD is $36 \mathrm{~km}$, and a discontinuous crustal root zone of up to $48 \mathrm{~km}$ and significant Moho topography has been identified from LITHOPROBE data. Currently there is no published evidence for a crustal root zone below the $\mathrm{CZ}$. The seismic Moho below the LB occurs at approximately $38 \mathrm{~km}$ depth (Durrheim et al., 1992), but an underlying Low Velocity Layer (LVL) to $56 \mathrm{~km}$ depth, composed predominantly of granulite is present, placing the petrologic base of the crust at about $56 \mathrm{~km}$ (Pretorius, 1996). The Moho topography therefore interpreted to deepen below the LB due to thicker/denser crust (e.g. Pratt-type isosatic mechanism). 
Constituents of the lithosphere from the base upwards may be determined from the xenolith compositions found in kimberlites, which are generated at the base of continental lithospheres. In the northern part of the Glennie Domain, kimberlites erupted at Fort a la Corne (FALC, 93Ma), Saskatchewan. In the Central Zone, kimberlites have intruded at the River Ranch (400 - 500Ma) and Venetia (530Ma, Allsopp et al, 1995) localities.

Table 1 summarises lithospheric composition at various levels in the two terranes:

\section{Location / Feature upper crust}

lower crust

upper lithospheric mantle lower lithospheric mantle

occurrence of metasomatism

depth to base of lithosphere diamonds

\section{Glennie Domain of the THO}

felsic-intermediate: phanerozoic cover, archean quartzite, granite and gabbro

intermediate-mafic: kyanite and quartz granulites, amphibolite and eclogite spinel lherzolite, eclogites, rare harzburgites garnet lherzolite, eclogite and increasing harzburgite towards the base of the lithosphere

rare, but throughout the mantle lithosphere due to both hydrous fluid and kimberlite melt interaction

$180 \mathrm{~km}$

2 distinct age groupings - archean and neoproterozoic

\section{Central Zone of the Limpopo Belt}

felsic-intermediate: archean quartzofelspathic gniess, quartzite, metapelite

mafic: amphibolite, granulite, garnet

pyroxenite and gabbro-norite

mafic eclogites

undifferentiated peridotites

rare evidence of metasomatism in the lower mantle due to kimberlite melt interaction

$180 \mathrm{~km}$

present, but undifferentiated

Two periods of diamond formation have been identified from Nitrogen aggregation characteristics of diamonds in FALC kimberlite: an Archaean growth period $(3.0-2.5 \mathrm{Ga})$ in lithosphere with a thickness of at least $150 \mathrm{~km}$ interpreted to be inherent to the GD (Leahy \& Taylor, 1997), and a second period of growth at $1.95-1.8 \mathrm{Ga}$. The latter is interpreted to be a direct consequence of the lithospheric thickening following collisional orogeny, and its subsequent depression into the diamond stability field beneath the THO (Leahy \& Taylor, 1997). By implication this negates delamination of the lithosphere beneath the GD during orogeny. Diamondiferous kimberlites intruding the $\mathrm{CZ}$ in the LB at River Ranch and at Venetia indicate that the lithosphere was thick and cool at the time of eruption (circa 450Ma). Lithospheric thickness below Venetia and River Ranch are presently on the order of $180 \mathrm{~km}$ (Pretorius, 1996; Kopylova et al, 1995). Unfortunately no diamond ages have been reported so far for any kimberlites in the LB. Preliminary and unpublished $\mathrm{Sm} / \mathrm{Nd}$ ages (Pretorius \& Barton) from mineral separates of eclogite from Venetia indicate Archaean $(-3.0 \mathrm{Ga})$ ages, pointing to the presence of old lithosphere. The Archaean crust below Venetia was at least $36-42 \mathrm{~km}$ thick between 3.2 - 2.88Ga (Pretorius, 1996) and may have doubled in thickness during crustal stacking and thrusting associated with the LB orogeny at $\sim 2.7 \mathrm{Ga}$.

\section{Lithospheric cratonization and implications for diamond prospectivity}

Estimates of effective elastic thickness (Te, a measure of the strength of lithosphere) are high for the Limpopo Belt and the Trans Hudson Orogen: 56km (LB \& southern ZC; Gwavava et al, 1992) and $75-100 \mathrm{~km}$ (THO; Pilkington, 1991). These values are similar to the adjacent cratons:. the KVC has a Te 72km (Doucoure et al, 1996), and the Superior Craton has a Te $100-150 \mathrm{~km}$ (Pilkington, 1991). However, Te significantly decreases towards the northern and north-western parts of the ZC (Pretorius \& Ebinger, unpublished data) and north-west towards the Hearne Craton (Te $-50 \mathrm{~km}$; Pilkington, 1991) respectively. The correlation between areas of high Te (strong) and cratons (which are by implication old, stable areas of low heatflow), has been clearly demonstrated 
by the compilation of global (Doucoure' et al, 1996) and regional African (Ebinger et al, 1997) Te data. In the case of the LB, this relationship may be explained by xenolithic evidence of Archean partial melting and devolatization, leading to an abundance of mechanically strong residual phases (Pretorius, 1996; Pretorius \& Barton, this volume). The cratonized area should be relatively less volatile rich, which in turn increases creep strength, elevates the solidus, modifying the thermal regime in the lithosphere to predominantly conductive regime (Pollack, 1986), making them relatively resistant to tectono-thermal perturbations. The coincidence between areas of high Te (strong) and "cratons", therefore, is not surprising. Analogous to the GD, it is probable that diamond growth also may have taken place when the LB lithosphere was downwarped into the diamond stability field during the $\sim 2.7 \mathrm{Ga}$ LB orogeny.

It seems clear that areas of high $\mathrm{Te}$, although certainly not an indicator of present day diamond prospectivity, may be pointers to areas which have at least good potential of having had some period(s) in its past which were favourable for diamond growth. Whether the diamond root is preserved and actually sampled by kimberlite magmatism, however, is clearly a function of the "cratons" tectono-thermal history relative to these diamond forming and diamond destroying processes. The need for detailed global compilations of variation of lithospheric strength, coupled with data pertaining to plume activity, tectonics and kimberlite emplacement ages, is clear in the future search for further diamond prospective regions.

\section{References}

Allsopp, H.L., Smith, C.B., Seggie, A.G., Skinner, E.M.W. \& Colgan E.A., 1995. The emplacement age and geochemical character of the Venetia kimberlite bodies. SA.J.Geol., 98, 239-244

Barton, J.M., Van Reenen, D.D. \& Roering, C. 1990. The significance of the 3000Ma granulite facies mafic dykes in the Central Zone of the Limpopo Beit, southern Africa. Prec. Res., 48, 299-308 Doucoure', M.C., De Wit, M.J. \& Mushayandebvu, M.F. 1996. Effective elastic thickness of the continental lithosphere in SA. J.Geophys.Res., 101, 11291-11303

Durrheim, R.J., Barker, W.H \& Green R.W.E 1992. Seismic studies in the Limpopo Belt. Prec. Res., 55, 187-200

Ebinger, C.J., Pretorius, W., Nixon, P.H. \& Whaler K.A, 1997. Lithospheric thickness and diamonds. Constraints from African gravity and magnetic data. Unpub. Report for BHP Minerals.

Gwavava,O., Swain, C.J. \& Podmore, F. 1996. Mechanisms of isostatic compensation of the Zimbabwe and Kaapvaal cratons, the Limpopo Belt, and the Mozambique basin. Geophys. J. Int., $127,635-650$

Kopylova. M.G. Gurney, J.J. \& Daniels, L.R.M., 1995. Mineral inclusions from diamonds from the River Ranch kimberlite. IKC6, Russia, 314-316

Leahy, K. \& Taylor, W.R., 1997.The Influence of deep structure of the Glennie Domain on the diamonds in Saskatchewan kimberlites. Extended abstracts, IKC6, Russia, 314-316

Lewry, J.F., Hajnal, Z., Green, A., Lucas, S.B., White, D., Stauffer, M.R., Ashton, K.E., Weber, W. \& Clowes, R. 1994. Structure of a Paleoproterozoic continent-continent collision zone.

Tectonophysics, 232, 143-160

Pilkington, M.,1991. Mapping effective elastic thickness variations in Canada. Tectonophysics, 190, 283-297

Pollack, H., 1986. Cratonization and thermal evolution of the mantle. EPSL, 80, 175-182

Pretorius, W., 1996. A geochemical and geophysical investigation of a suite of crustal and upper mantle nodules in Venetia pipes, Limpopo Belt, SA. Unpub. Mast. thesis, Rand Afrikaans University. Pretorius, W. \& Barton, J.M. The use of amphibolite melting experiments in constraining conditions of melting in (natural) amphibolite nodules from the Venetia kimberlite pipes, Limpopo Belt, SA. This volume. 